\title{
A new species of the hisponine jumping spiders from India (Araneae: Salticidae), with some observations on its life history
}

\author{
Новый вид пауков-скакунчиков хиспонин из Индии (Araneae: \\ Salticidae), с некоторыми наблюдениями наА его образом зкизни
}

\author{
Rajesh V. Sanap ${ }^{1}$, John T.D. Caleb ${ }^{2,}$, Anuradha Joglekar ${ }^{3}$ \\ P.B. Санап ${ }^{1}$, Ажк.Т.А. Калеб ${ }^{2,}$, А. Ажкоглекар ${ }^{3}$ \\ ${ }^{1}$ National Center for Biological Sciences, Tata Institute of Fundamental Research, Bangaluru - 560 065, Karnataka, India
${ }^{2}$ Zoological Survey of India, Prani Vigyan Bhavan, M-Block, New Alipore, Kolkata - 700 053, West Bengal, India. Email:
caleb87woodgate@gmail.com
${ }^{3}$ 706, Piccadilly 3, Royal Palms Estate, Aarey Milk Colony, Goregaon East, Mumbai - 400 065, Maharashtra, India
${ }^{*}$ Corresponding author
}

KEY WORDS: Aranei, bionomics, description, taxonomy, Mumbai, Jerzego.

КЛЮЧЕВЫЕ СЛОВА: Aranei, биономика, описание, таксономия, Мумбай, Jerzego.

ABSTRACT. A new species of the hisponine jumping spider genus Jerzego Maddison, 2014 — Jerzego sunillimaye sp.n. $\left(\bigcirc^{7}+\right)$ - is described. The species was found inhabiting the jungle floor of Aarey Milk Colony, Mumbai (Maharashtra, India). A detailed description and diagnostic illustrations of the species along with observations of mating, ovipostion, and postembryonic development are presented.

How to cite this article: Sanap R.V., Caleb J.T.D., Joglekar A. 2019. A new species of the hisponine jumping spiders from India (Araneae: Salticidae), with some observations on its life history // Arthropoda Selecta. Vol.28. No.1. P.113-124. doi: 10.15298/arthsel. 28.1.09

РЕЗЮМЕ. Описан новый вид пауков-скакунчиков хиспонин из рода Jerzego Maddison, 2014 Jerzego sunillimaye sp.n. $\left(\sigma^{7}+\right)$. Вид обитает в подстилке тропического леса колонии Арей Милк, Мумбай (Махараштра, Индия). Даны детальное описание и диагностические рисунки, а также наблюдения за поведением спаривания, откладкой яиц и постэмбриональным развитием.

\section{Introduction}

The hisponine jumping spider genus Jerzego Maddison, 2014 was recently erected by Maddison \& Piascik [2014]. Currently, the genus comprises three valid specieû, of which Jerzego bipartitus (Simon, 1903) is the only species known from the Indian subcontinent. Two other species are known from SE Asia: J. alboguttatus (Simon, 1903) from Sumatra and Borneo and J. corticicola Maddison, 2014 from Borneo [Maddison, Piascik, 2014; WSC, 2018]. In the present paper, a new species — Jerzego sunillimaye sp.n. found in the unique eco-sensitive, dry deciduous habitat of Aarey Milk Colony in Mumbai is diagnosed and described. In addition, some observations on the mating behaviour, oviposition and postembryonic development are documented.

\section{Material and methods}

During June-July 2017, eight females and two males were hand-collected. Of the collected females, four were used for a taxonomic study, two for observing mating behaviour, and two for observing the production of egg sacs and further postembryonic development of their offspring. Of the two collected males, one was used for a taxonomic study (the holotype), and both were used for observing mating behaviour. During August-December 2017, additional 15-20 females with egg sacs, as well as over 20 sub-adults were observed.

To observe egg and postembryonic development, gravid females were housed in clear, round plastic containers $(9 \mathrm{~cm} \times 6 \mathrm{~cm})$. Wet cotton was placed in the containers to maintain moisture. The containers were maintained at a room temperature at a $12 \mathrm{~L}: 12 \mathrm{D}$ light cycle. Spiders were fed with Drosophila.

Specimens were photographed by means of Canon DSLR 60D, 60-mm lens with Canon Speedlite 430 EX II, Canon Speedlite 600 EX-RT or Macro ring lite YN14EX external flash. The specimens were preserved in $70 \%$ ethanol and examined using a Leica S8APO stereoscopic microscope. Detailed micro-photographs were obtained using Leica M205 A stereomicroscope with a Leica DFC500 HD camera attached to it that is enabled with a Leica Application Suite (LAS) version 3.8. The epigyne was dissected and macerated in $10 \%$ $\mathrm{KOH}$ to clear soft tissue. Temporary preparations were observed and photographed by means of a Leica DM1000 compound microscope with a Leica EC3 camera attached to it. Line drawings were prepared with the GNU Image Manipulation Program (GIMP) [Mon- 

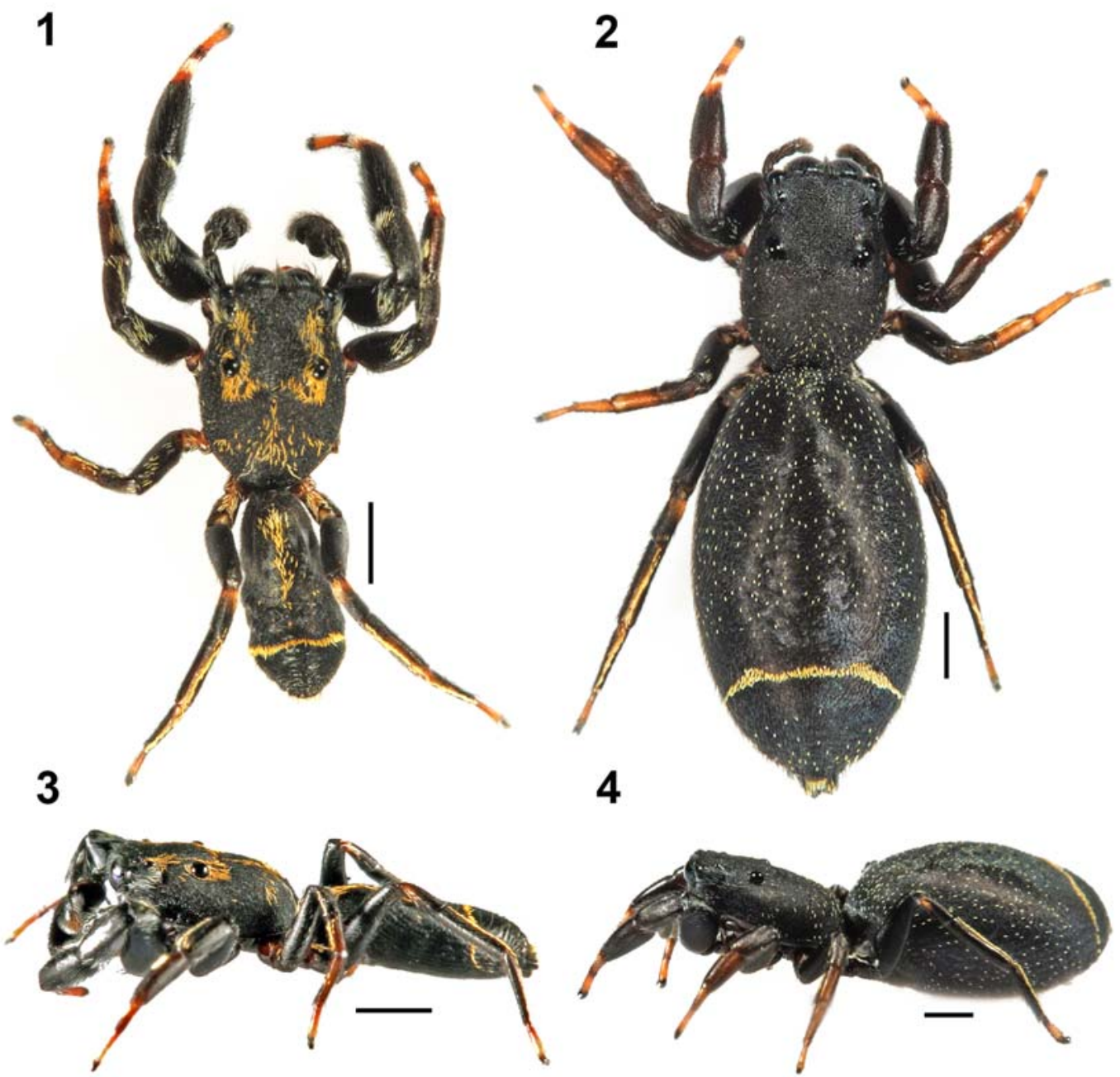

Figs 1-4. General appearance of Jerzego sunillimaye sp.n., holotype male $(1,3)$ and paratype female $(2,4): 1,2$ — dorsal view; 3,4 lateral view. Scale bars: $1 \mathrm{~mm}$.

Рис. 1-4. Внешний вид Jerzego sunillimaye sp.n., голотип-самец $(1,3)$ и паратип-самка $(2,4): 1,2$ — вид сверху; $3,4-$ вид сбоку. Масштаб: 1 мм.

tesanto, 2015]. Leg measurements are given as follows: total length (femur, patella, tibia, metatarsus and tarsus). All measurements are in mm. Spine positions are as follows: prolateral, dorsal, retrolateral and ventral. The type specimens are deposited in the research collection facility of the National Centre for Biological Sciences (NCBS), Bengaluru, Karnataka, India.

Abbreviations used in the text are as follows: AER anterior eye row; ALE - anterior lateral eye; AME anterior median eye; PLE - posterior lateral eye; PME posterior median eye; RTA — retrolateral tibial apophysis.

\section{Taxonomy}

Genus Jerzego Maddison, 2014

\section{Jerzego sunillimaye sp.n.}

Figs 1-55, Map.

TYPE. Holotype $\sigma^{7}$ (NCBS-BB968) from Aarey Milk Colony $\left(19^{\circ} 8^{\prime} 37.4922^{\prime \prime} \mathrm{N}, 72^{\circ} 52^{\prime} 51.459^{\prime \prime} \mathrm{E}\right.$; $61 \mathrm{~m}$ a.s.1.), Mumbai, Maha- rashtra, India, 16 June 2017, R.V. Sanap. - Paratypes (from the same locality): 1 우 (NCBS-AW273), 21 June 2016; 3 우 (NCBSBB969 to BB971), 16 June 2017, R.V. Sanap.

ETYMOLOGY. The specific epithet is a noun in apposition, honoring our friend and the respected forest officer $\mathrm{Mr}$ Sunil Limaye, the Additional Principal Chief Conservator of Forest (APCCF, Wildlife-East, Maharashtra, India), who is involved in the conservation of urban biodiversity in Mumbai and the neighbouring areas. We honor him for his valuable support to various conservation projects in Mumbai, which is the type locality of the new species.

DIAGNOSIS. By its dark grey body coloration, the new species resembles $J$. corticicola Maddison, 2014, but can be easily distinguished from it by the larger body size and a different colour pattern: abdomen with a transverse crescent shaped golden-yellow stripe in its posterior half (Figs 1,2). The males can be readily distinguished by the unique palpal conformation: the flattened and twisted embolus (short and simple in $J$. corticicola), and the larger and wider RTA (small in J. corticicola) (cf. Figs 5, 6, 16, 17 with figs 1, 2 in Maddison \& Piascik [2014]). The females can be distinguished from those of $J$. corticicola by the medially placed 

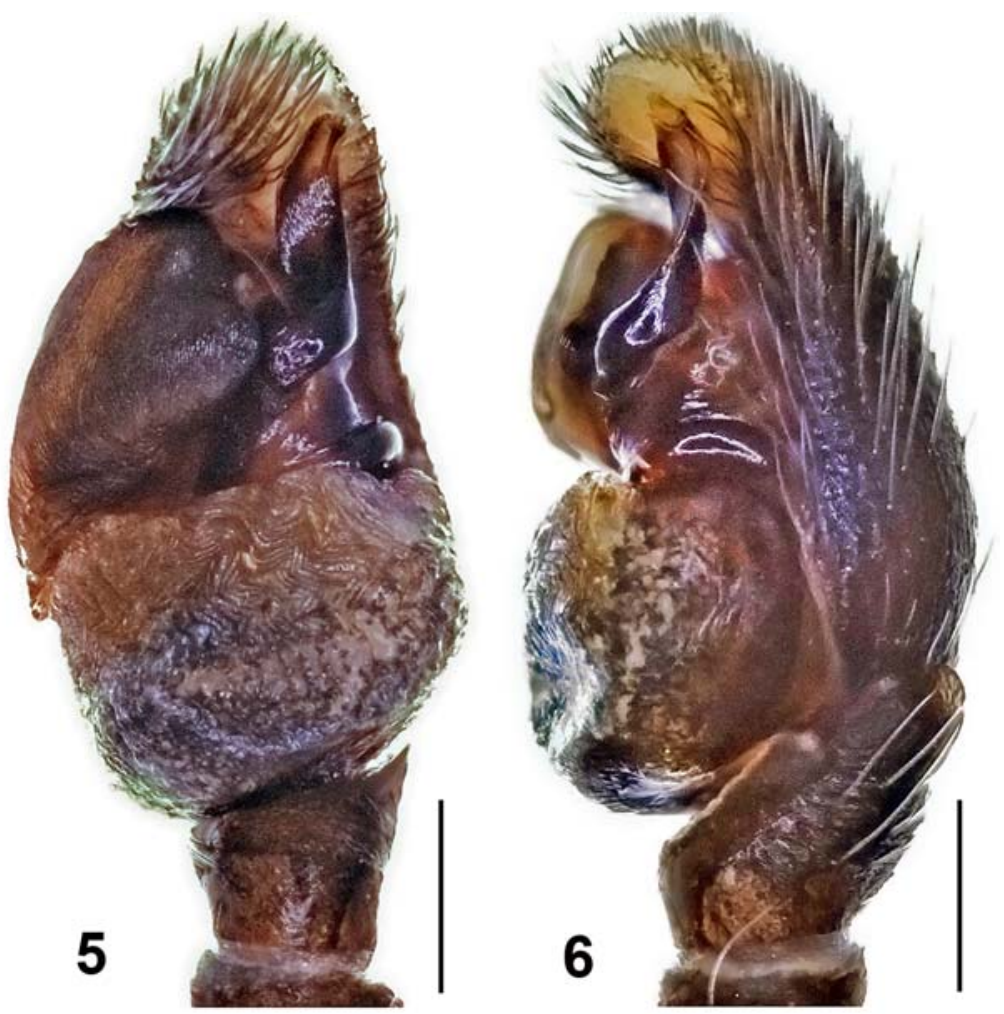

Figs 5-6. Male palp of Jerzego sunillimaye sp.n. (the holotype): 5 - ventral view, 6 - retrolateral view, Scale bars: $0.2 \mathrm{~mm}$. Рис. 5-6. Пальпа самца Jerzego sunillimaye sp.n. (голотип): 5 - вид снизу, 6 - вид сбоку-сзади, Масштаб: 0,2 мм.
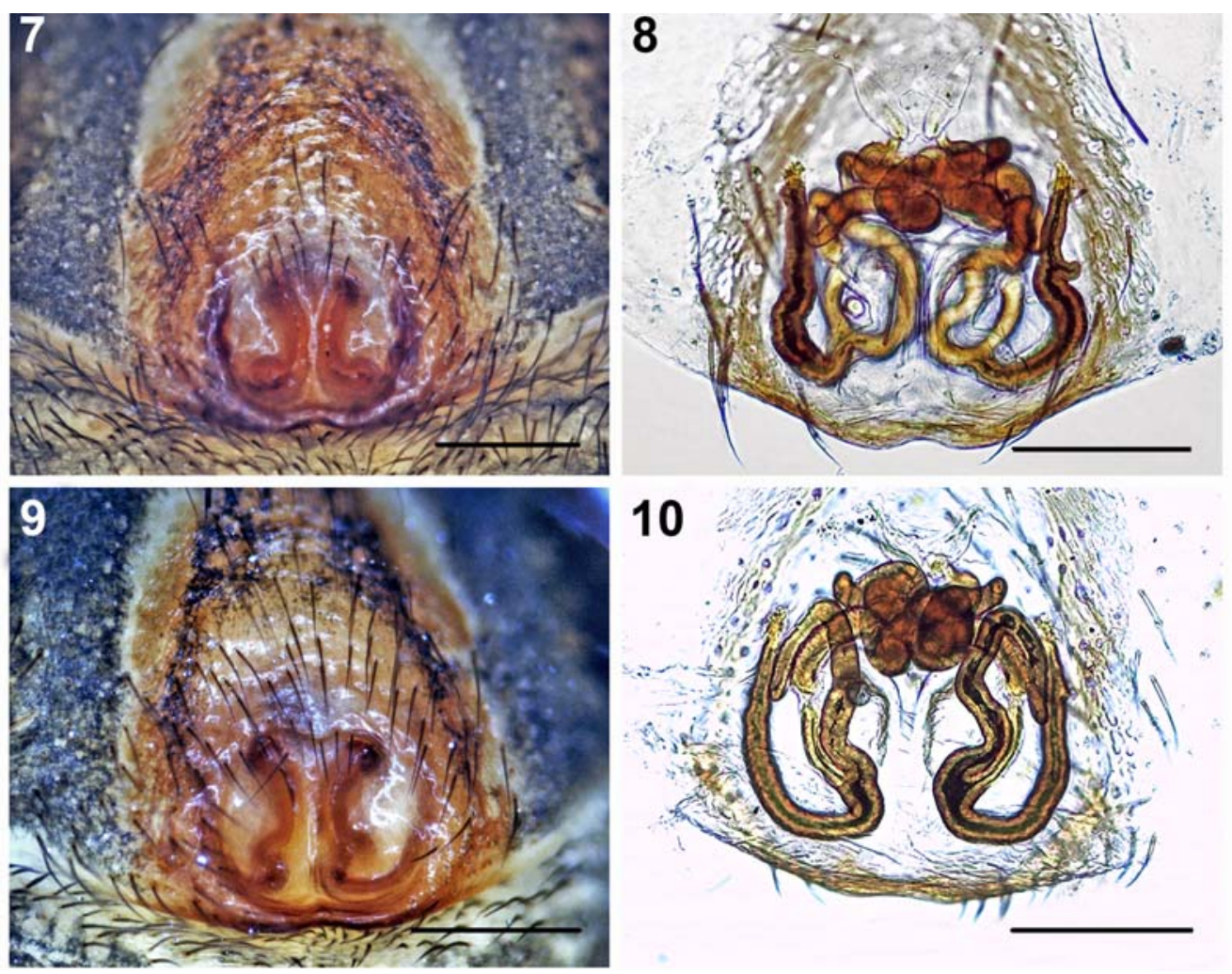

Figs 7-10. Female copulatory organs of Jerzego sunillimaye sp.n., NCBS-BB969 $(7,8)$ and NCBS-BB970 $(9,10): 7,9$ - epigyne, ventral view; 8,10 - spermathecae, dorsal view. Scale bars: $(7,9) 0.2 \mathrm{~mm} ;(8,10) 0.1 \mathrm{~mm}$.

Рис. 7-10. Копулятивные органы самки Jerzego sunillimaye sp.n., NCBS-BB969 $(7,8)$ и NCBS-BB970 $(9,10): 7,9$ — эпигина, вид снизу; 8, 10 - сперматека, вид сверху. Масштаб: $(7,9) 0,2$ мм; $(8,10) 0,1$ мм. 

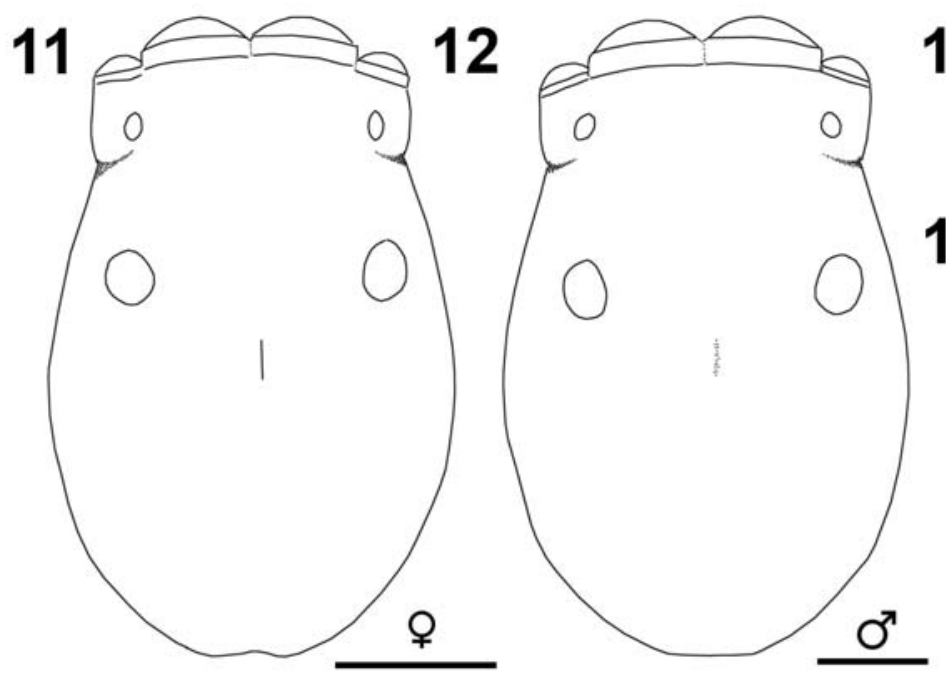

13

14
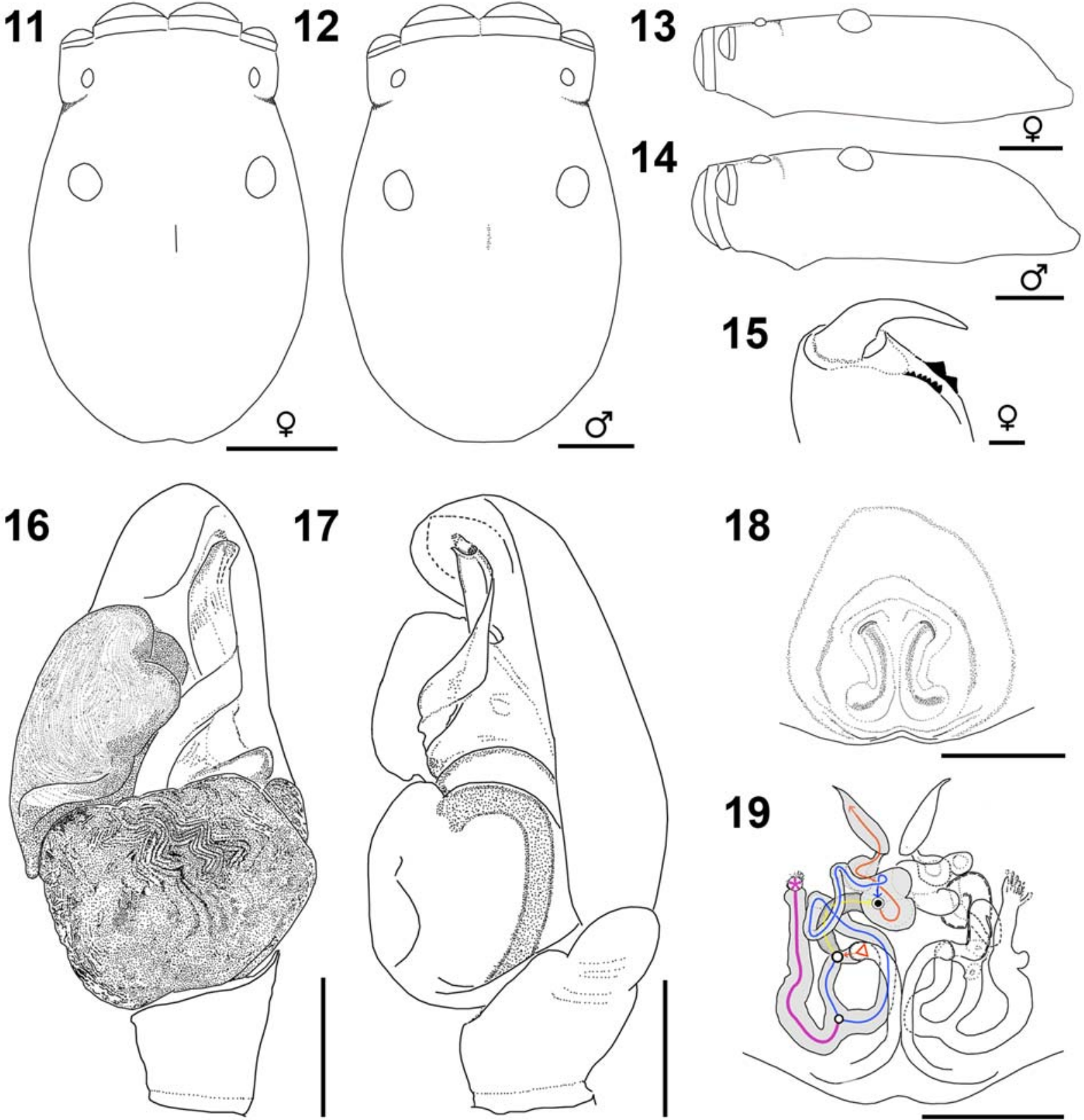

Figs 11-19. Jerzego sunillimaye sp.n., holotype male $(12,14,16,17)$ and paratype female (NCBS-AW273; 11, 13, 15, 18, 19): 11, 12 carapace, dorsal view; 13,14 - ditto, lateral view; 15 - female chelicera; 16 - male left palp, ventral view, 17 - ditto, retrolateral view; 18 - epigyne, ventral view; 19 - spermathecae, dorsal view. Scale bars $(11,13) 1 \mathrm{~mm} ;(12,14) 0.5 \mathrm{~mm}$; $(16-18) 0.2 \mathrm{~mm} ;(15,19)$ $0.1 \mathrm{~mm}$.

Рис. 11-19. Jerzego sunillimaye sp.n., голотип-самец $(12,14,16,17)$ и паратип-самка (NCBS-AW273; 11, 13, 15, 18, 19): 11, 12 головогрудь, вид сверху 13,14 - тоже, вид сбоку; 15 - хелицера самки; 16 - левая пальпа самца, вид снизу, 17 - тоже, вид сбоку-сзади; 18 - эпигина, вид снизу; 19 - сперматека, вид сверху. Масштаб $(11,13) 1$ мм; (12, 14) 0,5 мм; (16-18) 0,2 мм; (15, 19) 0,1 мм.

copulatory openings and the anteriorly positioned spermathecae situated above the copulatory openings (Figs 7-10, 1819) (at the postero-medial position and below the copulatory openings in $J$. corticicola) (cf. figs $3-5$ in Maddison \& Piascik [2014]).

TAXONOMIC NOTES. Maddison \& Piascik [2014] erected the new genus Jerzego on the basis of the simple palpal conformation along with the features earlier men- tioned by Wanless [1981], such as the flat carapace, the presence of fovea, the sternum narrowing anteriorly, and the anteriorly placed copulatory openings. As compared to the described Jerzego species, the male palp of $J$. sunillimaye sp.n. is unique, showing a relative complexity (Figs 5, 16) and being dissimilar with the short, terminally pointing, simple embolus in the generotype of Jerzego (cf. fig. 1 in Maddison \& Piascik [2014]). Although the new species 


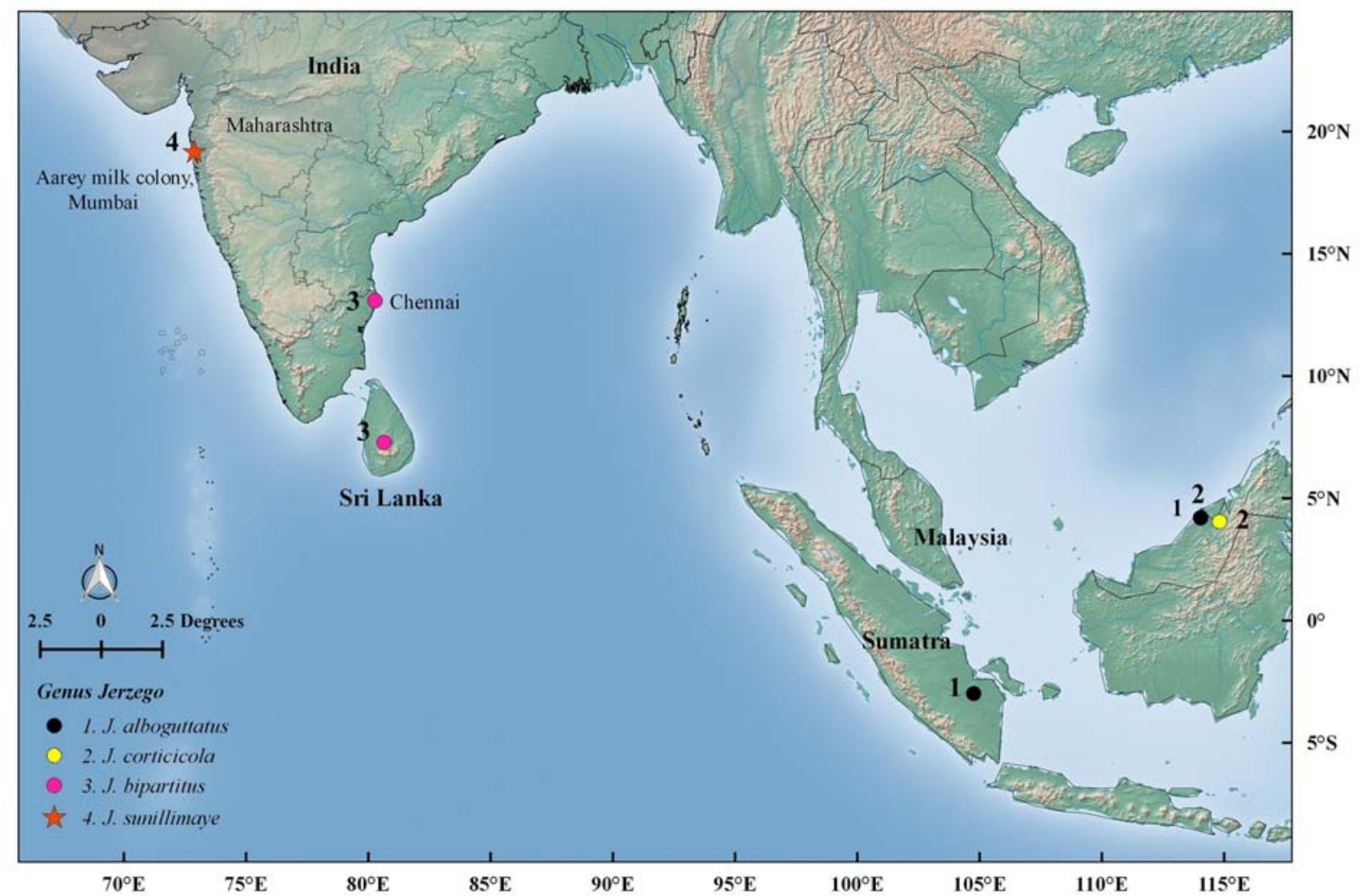

Map. Collecting localities of Jerzego species: 4 - orange star indicates the type locality of Jerzego sunillimaye sp.n.

Карта. Точки сбора видов Jerzego: 4 - оранжевая звезда показывает типовой локалитет Jerzego sunillimaye sp.n.

could warrant placing it in a genus of its own, we have tentatively considered it in the genus Jerzego reasoning from the fact that the true diversity of the 'hisponines' in Asia is yet relatively poorly known. Besides, the new species shares the four diagnostic characters of Jerzego with other congeners (see above). It is possible that either $J$. sunillimaye sp.n., or $J$. corticicola possess a derived palp, either simplified (in J. corticicola) or elaborated (in J. sunillimaye sp.n.) (Maddison pers. comm.). The matter needs further studies when more Jerzego species have been described.

DISTRIBUTION. India, Mumbai (Map).

DESCRIPTION. MALE (holotype). Total length: 5.52, carapace: 2.72 long, 1.79 wide; abdomen: 2.80 long, 1.41 wide. Carapace black, covered with pale hairs and pale yellow scales scattered intermittently (Fig. 1). Greyish hairs cover the clypeal region (Fig. 24). Eye diameter: AME 0.52, ALE 0.26, PME 0.09, PLE 0.25. Eye interdistances: AMEAME 0.02; AME-ALE 0.01; ALE-PME 0.18; PME-PME 1.04; PME-PLE 0.55; PLE-PLE 0.95. Sternum dark brown; chelicerae reddish brown, pluridentate, with three large promarginal and seven small retromarginal teeth. Labium and maxillae reddish brown, with paler inner margins. Legs dark brown; tarsi I, II, proximal region of patellae III, IV and all metatarsi yellowish; white scales present on femora, patellae and tibiae I-III (Figs. 1, 3). Leg measurements: I 4.96 (1.45, $1.02,1.11,0.79,0.59)$; II 4.06 (1.20, 0.87, 0.83, 0.61, 0.55); III $3.77(1.11,0.67,0.72,0.81,0.46)$; IV $5.03(1.46,0.78$, $1.17,1.10,0.52)$. Leg formula: 4123 . Leg spination: femora I 0300; II 0300, III 0200, IV 0200; tibiae I 0000, II 0000, III 0001, IV 0001; metatarsi I 0002, II 0001, III 0002, IV 0002.
Abdomen elongate-oval, with small antero-dorsal scutum; greyish, covered with short pale hairs; yellowish white scales scattered on the dorsum; a transverse stripe of yellowish scales present in the posterior region (Fig. 1); venter greyish black. Spinnerets black. Palp blackish, cymbium dorsally covered with greyish setae; embolus flattened and twisted distally; bulbus consists of two distinct lobe-like structures: a prolateral lobe with a fine fingerprint-like pattern, adjacent to the embolus and a wrinkled lobe below the embolus, occupying the entire posterior part of bulbus; median apophysis absent; RTA broad (Figs 5, 6, 16, 17).

Female. Total length: 10.30 , carapace: 3.79 long, 2.53 wide; abdomen: 6.51 long, 3.47 wide. Eye diameter: AME 0.62, ALE 0.32, PME 0.12, PLE 0.32. Eye interdistances: AME-AME 0.04; AME-ALE 0.04; ALE-PME 0.28; PMEPME 1.44; PME-PLE 0.73; PLE-PLE 1.38. Leg measurements: I $5.04(1.59,1.13,1.09,0.61,0.62)$; II 4.73 (1.47, $1.07,0.95,0.62,0.62)$; III $4.65(1.37,0.84,0.89,0.97$, $0.58)$; IV $6.45(1.82,1.07,1.54,1.37,0.65)$. Leg formula: 4123. Leg spination: femora I 0000; II 0000, III 0100, IV 0000; tibiae I 0000, II 0000, III 0001, IV 0002; metatarsi I 0002, II 0000, III 0003, IV 0003. Coloration as in the male except for the following: carapace reddish brown, white scales scattered intermittently; eye region black, finely rugulose (Fig. 2). Sternum yellowish brown. Chelicerae orangebrown, pluridentate, with three-four large promarginal and eight small retromarginal teeth (Fig. 15). Labium and maxillae yellowish brown. All femora dark brown, all legs patellae to tarsi yellow-brown; tibia III with a yellowish white stripe laterally; tibia IV and metatarsus IV with a dorsal stripe of yellowish white hairs; tibia II with small patch 

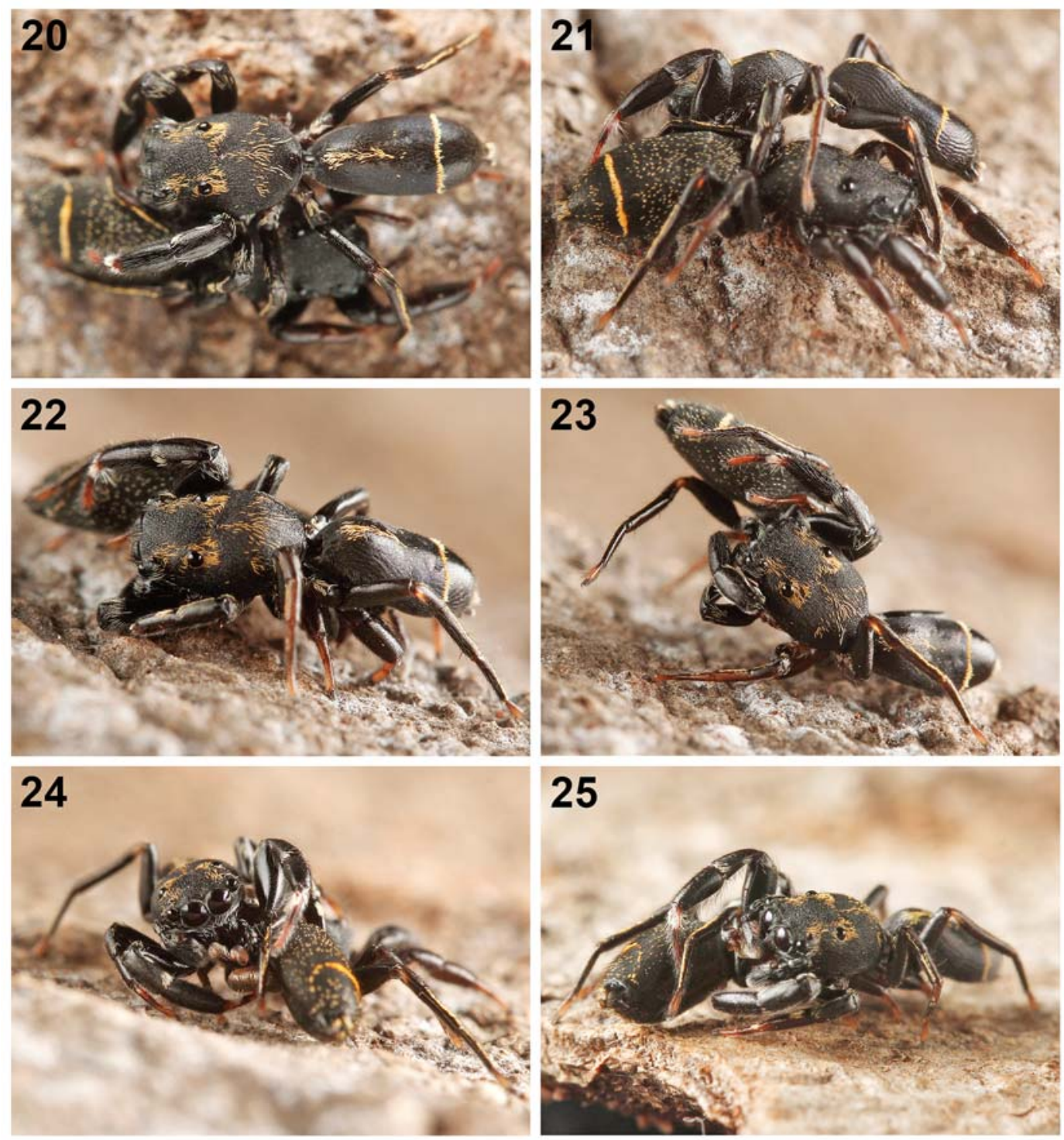

Figs 20-25. Mating behaviour of Jerzego sunillimaye sp.n.; images depicting the sequence of the events during the courtship and mating processes.

Рис. 20-25. Поведение спаривания у Jerzego sunillimaye sp.n.; изображения представляют последовательность событий во время ухаживания и спаривания.

prolaterally, metatarsi I and II covered with thin annulation of white hairs in the proximal half; all legs covered uniformly with thick setae (Figs 2, 3). Abdomen blackish, covered with uniformly scattered, yellowish white scales and with a transverse yellowish stripe in the posterior region; dorsal scutum absent (Fig. 2); mid-venter region beige. Spinnerets brownish. Epigyne with copulatory openings placed in subparallel, curved longitudinal grooves separated by a median septum (Figs 7, 9). The opening leads to two diverging ducts: the duct of accessory glands that runs posteriorly and branches laterally to a longitudinal duct bearing the accessory glands at its tip; and the insemination duct that runs anteriorly making twists and coils just above the copulatory openings and joins the accessory gland duct before entering the anteriorly placed spermathecae; each spermatheca small and globular (Figs 8, 9, 19).
SEXUAL DIMORPHISM. Both sexes look very similar (Figs 1-4, 27). The males have the eyebrow looking like a band of yellow hairs at PMEs and PLEs (absent in the females); the anterior region of their dorsum with a yellow band in the middle, extending to the half of the dorsum length (absent in the females); both the males and the females with a transverse crescent-shaped yellow band in the posterior region of the dorsum. The pattern of yellow hairs on the male carapace and the transverse crescent-shaped yellow band on the posterior region of the female dorsum vary.

MATING BEHAVIOUR. A female was housed in a clear container, with a thin layer of soil and a wood piece serving as a substrate. The female built a silken retreat under the wood, and then a male was introduced to the same container. The male wandered around and finally managed 

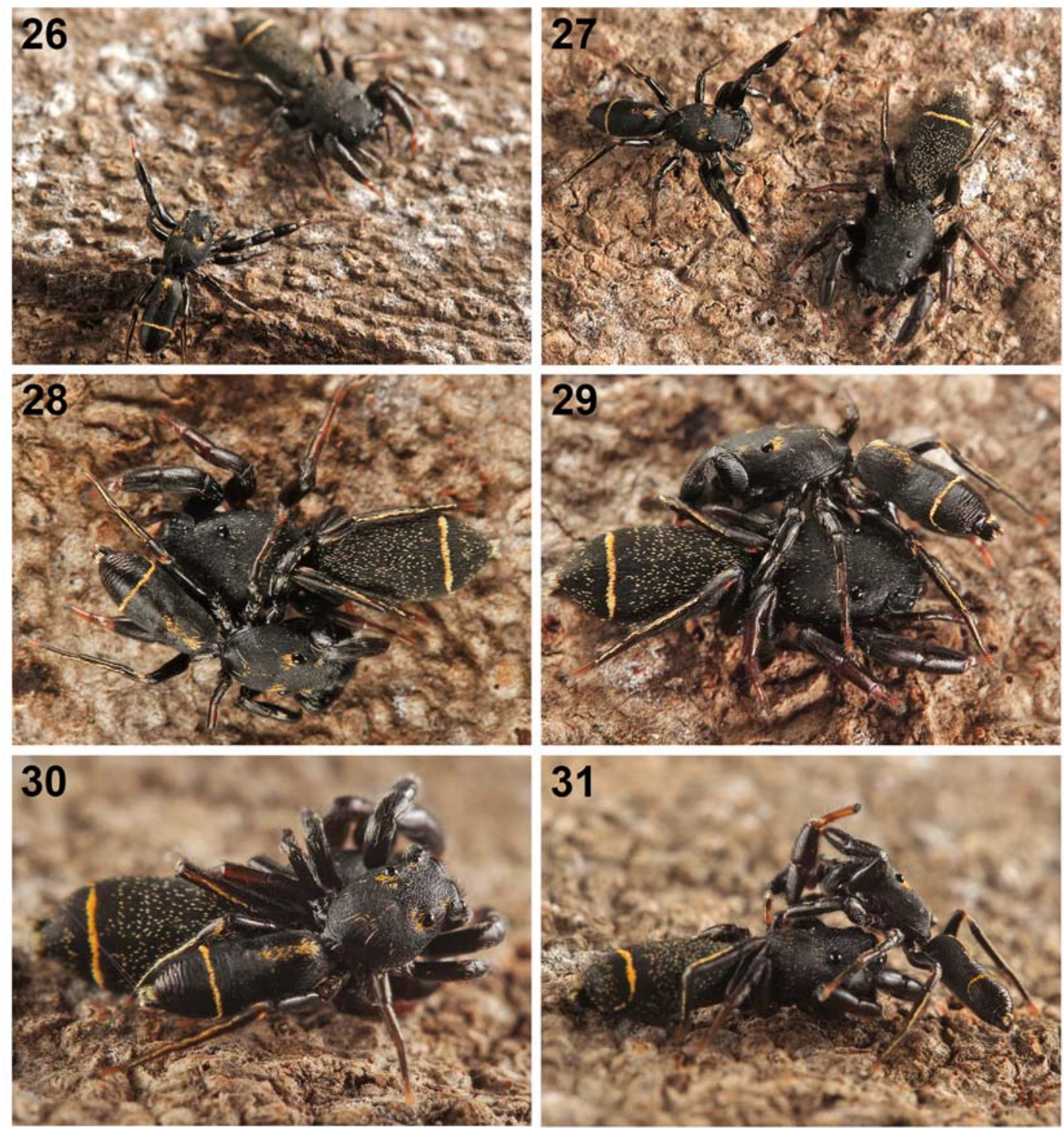

Figs 26-31. Mating behaviour of Jerzego sunillimaye sp.n.; images depicting the sequence of the events during the courtship and mating processes.

Рис. 26-31. Поведение спаривания у Jerzego sunillimaye sp.n.; изображения представляют последовательность событий во время ухаживания и спаривания.

to get under the wood piece. Having recognized the presence of the female, the male began a courtship display by approaching the female with the first two legs extending sideways, abdomen being kept low and carapace high. The female responded to it by displaying in a similar manner. However, when the male had approached the retreat she started to show an aggression by rapidly moving the first pair of legs and attempting to block the retreat's entrance by the retraction of silk webbing by chelicerae. Nonetheless, the male tried to forcefully entry into the retreat causing the female to abandon it.

At another occasion (July 3rd, 2017) (Figs 26-31), a male and a female were introduced in the same container simultaneously. The male immediately began his display in the same manner as described earlier and approached the female. However, the mating was unsuccessful probably because of a considerably smaller body size of the male compared to the female. A bigger male (the holotype) (Figs 20-25) was introduced to the same container instead of the smaller male. It approached the female after displaying, mounted her from the lateral side of the abdomen, and lifted it in order to reach the epigyne. The mating lasted for about 1-2 minutes; then the male and the female broke up.

OVIPOSITION, MATERNAL CARE AND POSTEMBRYONIC DEVELOPMENT IN CAPTIVITY. Gravid females $(n=2)$ were housed in containers provided with a thin layer of soil and wood pieces serving as substrate. Both females laid eggs on June 24th, 2017. The egg sac attached to the wood underside was covered with two layers of webbing. Another layer of smooth and comparatively thick webbing was laid covering the female roosting over the egg sac, followed by a layer of scattered webbing, without any defined opening (Figs 32-34). One egg sac was left undisturbed to observe a parental care. During this period (June 

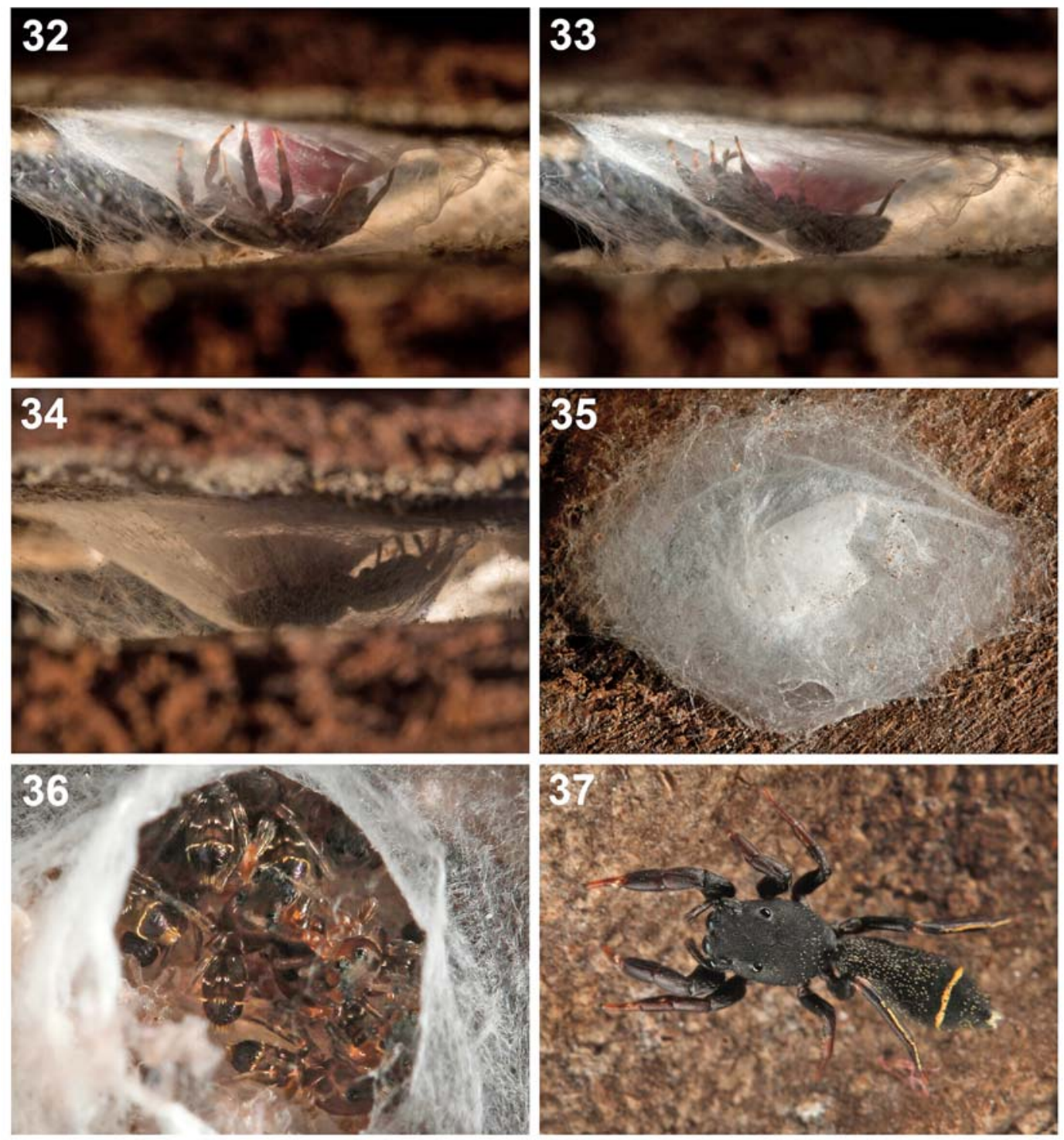

Figs 32-37. Maternal care of Jerzego sunillimaye sp.n. in captivity: 32 - female with the egg sac (June 24th, 2017); 33 — 34 egg sac attached to the underside of wood covered with two layers of webbing; 35, 37 - female left the eggs sac on day 24 (July 17th, 2017); 36 nymphs, on day 24 (July 17th, 2017).

Рис. 32-37. Материнская забота у Jerzego sunillimaye sp.n. в неволе: 32 - самка с яйцевым коконом (24 июня 2017 г.); 33 кокон с 34 яйцами, прикрепленный к нижней поверхности древесины, с двумя слоями паутины; 35, 37 - самка покинула яйцевой кокон на 24-й день (17 июля 2017 г.); 36 - нимфы на 24-й день (17 июля 2017 г.).

24th-July 17th, 2017), the female occasionally adjusted the egg sac and cleaned it. After about 3 weeks (Figs 35-36), she left the egg sac (Fig. 37). In the second container, the female was separated from the egg sac, which was then carefully opened to observe egg development. There were 40 eggs in total. The development was monitored from the nymph stage to the dispersion of spiderlings. Spiderlings $(\mathrm{n}=22)$ were housed in separate containers and fed with Drosophila (collected by baiting). The following observations regarding a postembryonic development have been recorded.

A large pink yellow spot appeared on eggs, covering approximately a half of the egg surface (Fig. 38; June 29th, 2017). The following day eggs showed signs of their devel- opment into body parts, such as legs and abdomen (Figs 3941 ; June 30 th - July 2 nd). The nymphs were completely out of their thin shells/egg cases (Fig. 42; July 3rd). The abdomen was dark pink, and AMEs began to appear as light brown spots. No major changes were observed in the following two days except for the darkening of eyes and brown patches on the posterior part of the carapace. The coloration further darkened from pink to brownish pink (Fig. 43; July 4th). Greyish bands appeared on femora and patellae (Fig. 44; July 6th). They underwent their first moulting on July 10th (Fig. 47). In the following days, the nymphs only further darkened in their overall coloration (Figs 48, 49).

NATURAL HISTORY. The type locality is covered with thick canopy (45-82\%), largely dominated by trees, such as 

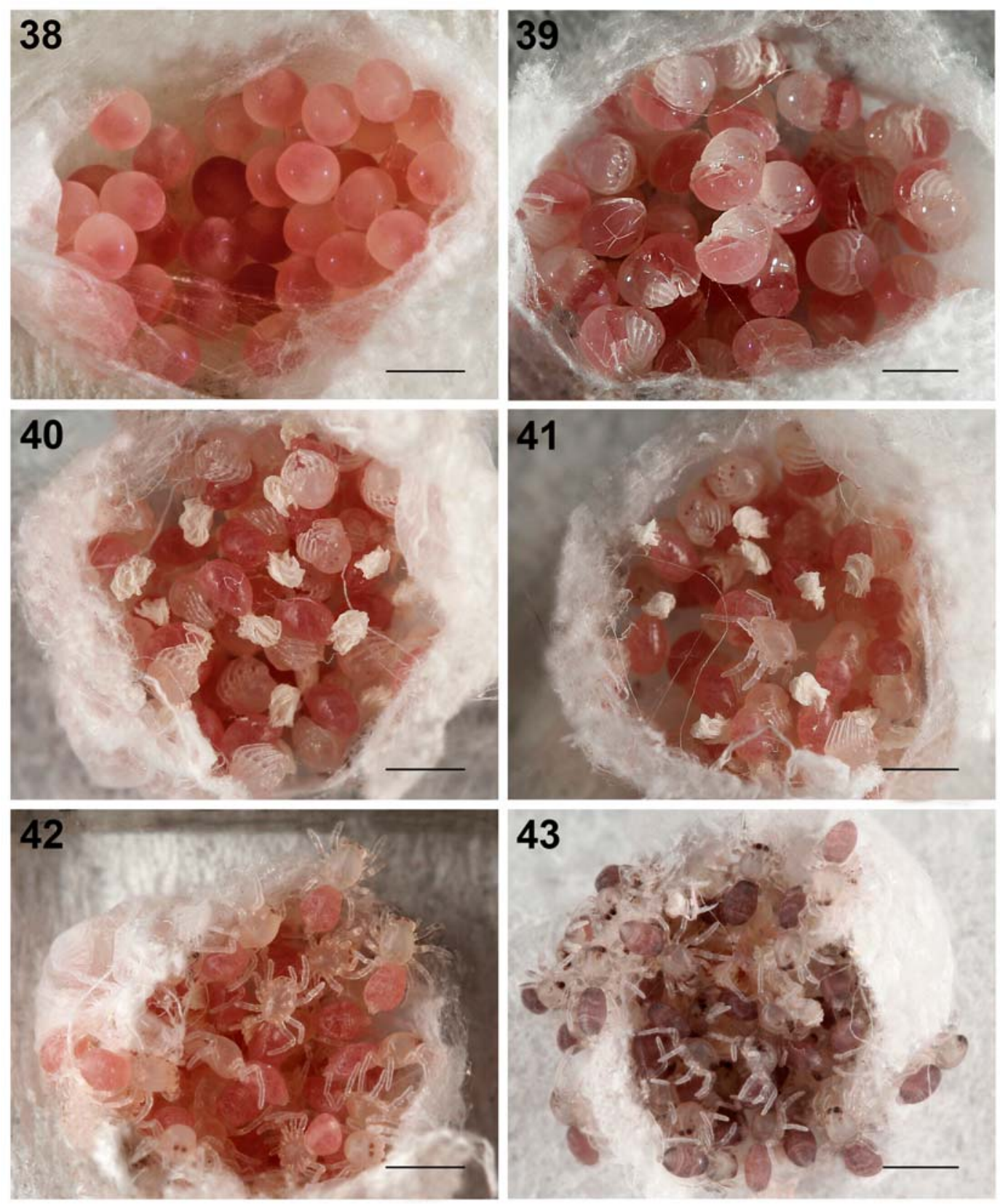

Figs 38-43. Egg development in Jerzego sunillimaye sp.n.: 38 - eggs, day 1 (June 29th, 2017); 39 - ditto, day 2 (June 30th, 2017); 40 - ditto, day 3 (July 1st, 2017); 41 - nymphs, day 4 (July 2nd, 2017); 42 - ditto, day 5 (July 3rd, 2017); 43 - ditto, day 6 (July 4th, 2017). Scale bars: $1 \mathrm{~mm}$.

Рис. 38-43. Развитие яиц у Jerzego sunillimaye sp.n.: 38 - яйца, день 1 (29 июня 2017 г.); 39 - то же, день 2 (30 июня 2017 г.); 40 - то же, день 3 (1 июля 2017 г.); 41 — нимфы, день 4 (2 июля 2017); 42 — то же, день 5 (3 июля 2017 г.); 43 — то же, день 6 (4 июля 2017). Масштаб: 1 мм.

Mangifera indica, Adenanthera sp., Acacia auriculiformis and Anacardium occidentale (tree trunk diameters, 93-355 $\mathrm{cm}$ ) (Figs 56-57). The forest floor is covered with dry leaf litter, and the habitat is also shared by other jumping spiders such as Hasarius sp., Stenaelurillus sp., Langelurillus sp. and Langona sp. [Sanap et al., 2017]. Several males and females of various life stages were observed (Figs 50-53). Some females were observed guarding their egg sacs (Figs 54-55). Variations in the vegetation cover in the landscape during the summer and rainy seasons are shown in Figs 58-
61. Specimens were mostly found on the underside of rocks or in dry leaf litter and sometimes under tree barks at approximately $20-90 \mathrm{~cm}$ above the ground-level, whereas all sub-adults were found dwelling on the ground, underneath rocks.

Interestingly, four to five sub-adults of $J$. sunillimaye sp.n. were observed nearby small brown ants of the genus Crematogaster Lund, 1831. By their coloration, these subadults appeared similar to the ants. Two to three adult females with egg sacs were observed under rock surface, being 

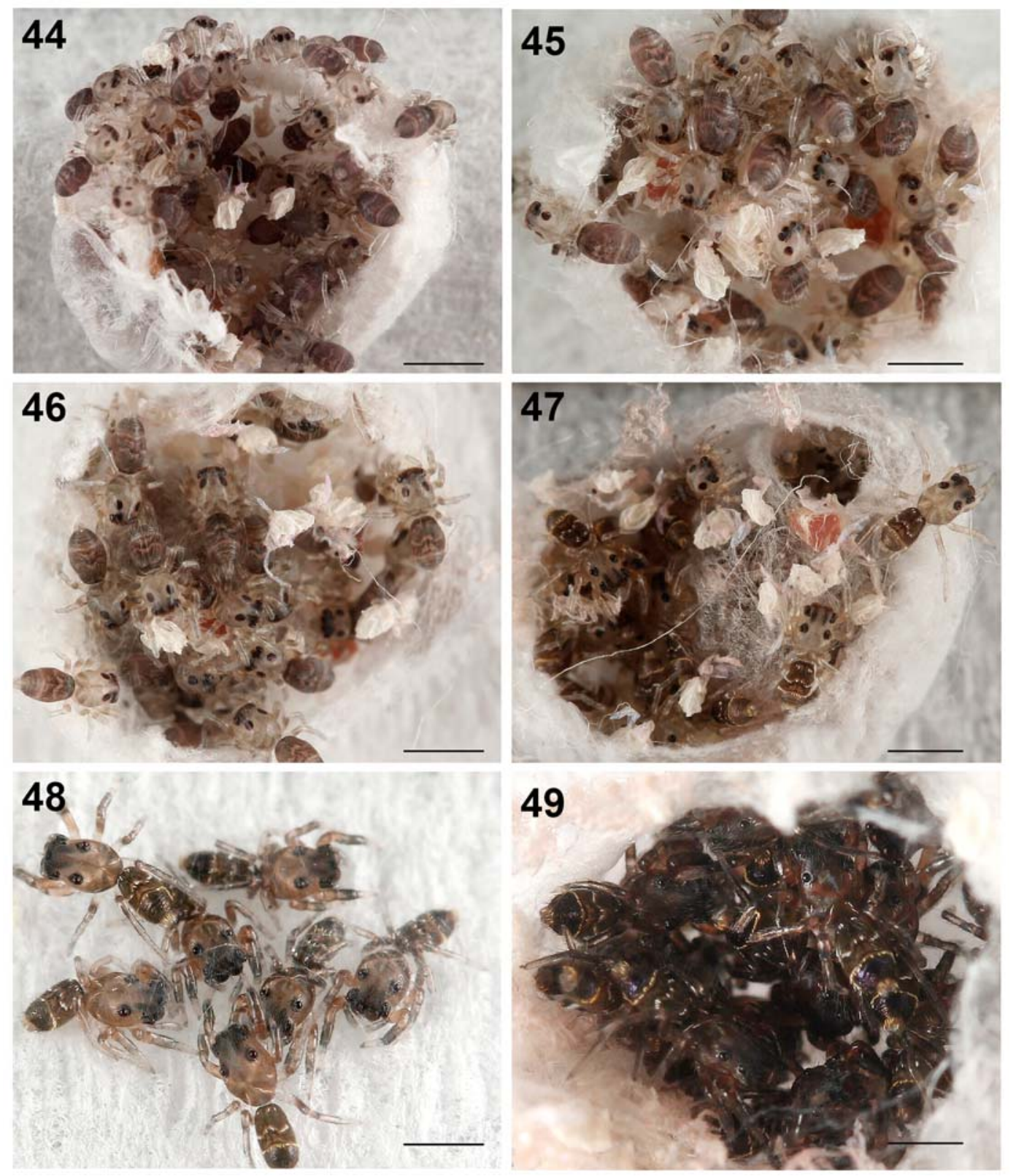

Figs 44-49. Nymph development in Jerzego sunillimaye sp.n.: 44 - nymphs, day 8 (July 6th, 2017); 45 — ditto, day 10 (July 8th, 2017); 46 - ditto, day 12 (July 10th, 2017); 47 - nymphs after the first moult, day 14 (July 11th, 2017); 48 — ditto, day 16 (July 13 th, 2017) 49 — ditto, day 17 (July 14th, 2017). Scale bars: $1 \mathrm{~mm}$.

Рис. 44-49. Развитие нимф у Jerzego sunillimaye sp.n.: 44 - нимфы, день 8 (6 июля 2017 г.); 45 - то же, день 10 (8 июля 2017); 46 — то же, день 12 (10 июля 2017 г.); 47 — нимфы после первой линьки, день 14 (11 июля 2017 г.); 48 — то же, день 16 (13 июля 2017 г.) 49 - то же, день 17 (14 июля 2017 г.). Масштаб: 1 мм.

surrounded by small black ants of the genus Paratrechina Motschulsky, 1863. However, there is no evidence to suggest a mimetic relationship with the ants and further behavioral studies are warranted.

Acknowledgements. We express our sincere thanks to Dr Krushnamegh Kunte, National Centre for Biological Sciences (NCBS), TIFR, for allowing us to use the stereomicroscope facility and deposit specimens. We also thank Dr Kailash Chandra, Director, ZSI for the support and encour- agement. John Caleb gratefully acknowledges the American Arachnological Society for the Herb Levi Memorial Fund for Arachnological Research (HLMFAR). We thank Dr Wayne Maddison (Vancouver, Canada) for his helpful insights during the course of this work. Rajesh Sanap and Anuradha Joglekar specially thank Ranjeet Jadhav, Siddhesh Waghamare, Imran Udat, Kishor Patre, Kunal Chaudhary, Sagar Rajpurkar, Prabu Swami, Kushal Dubey and Karan Kothari for their logistic support and assistance during the field work. Finally, our profound thanks go to Dr Dmitri 

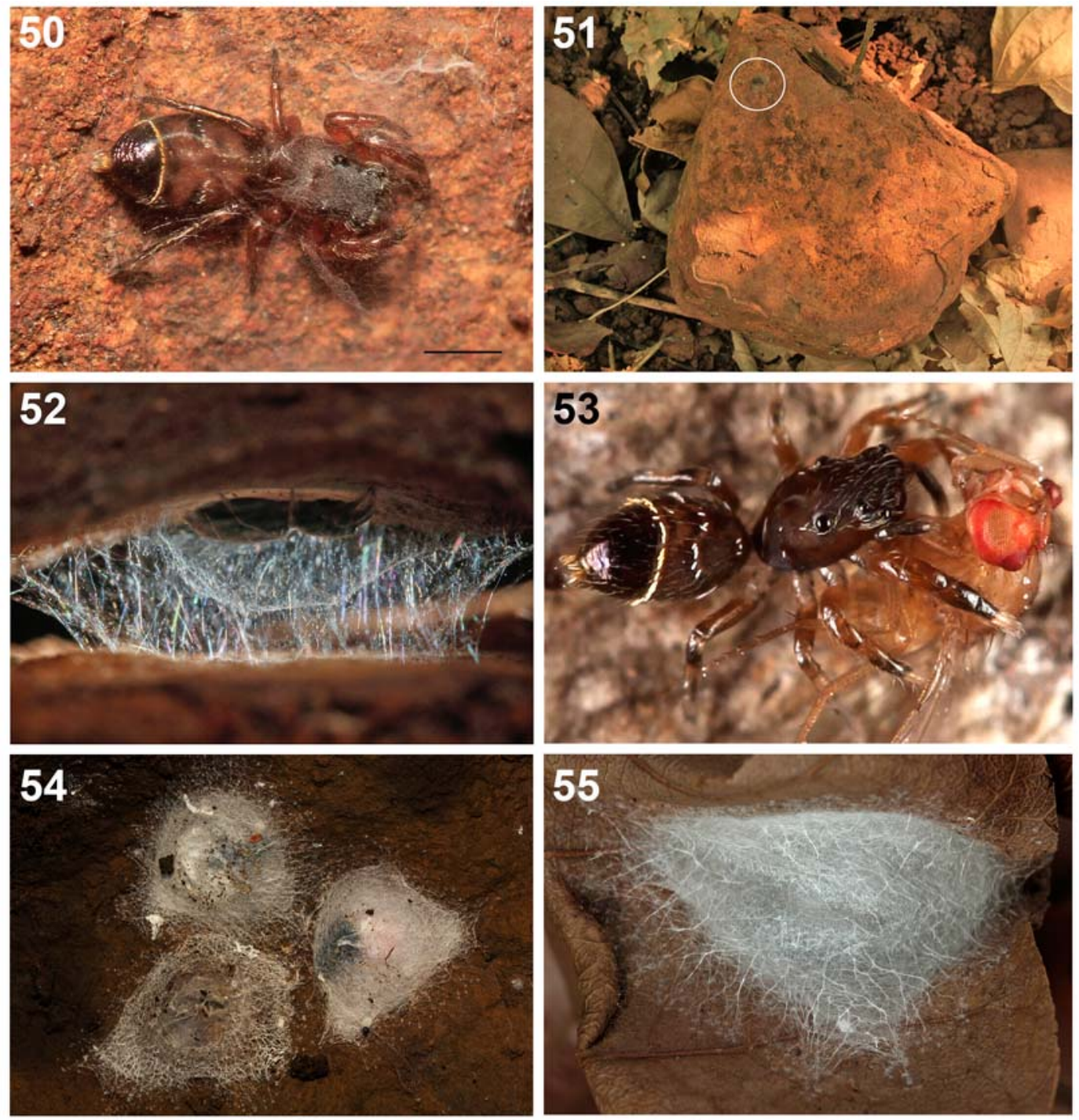

Figs 50-55. Observations on Jerzego sunillimaye sp.n. in the wild: 50-53 - adult females with eggs sac under the rock and dry leaf litter; 54, 55 - sub-adults. Scale bar: (50) $1 \mathrm{~mm}$.

Рис. 50-55. Наблюдения над Jerzego sunillimaye sp.n. в природе: 50-53 - взрослая самка с яйцевым коконом под камнем и сухой листовой подстилкой; 54, 55 - субадультные особи. Масштаб: (50) 1 мм.

Logunov (Manchester, UK) for his positive comments on the manuscript, helping us to improve it.

\section{References}

Maddison W.P., Piascik E.K. 2014. Jerzego, a new hisponine jumping spider from Borneo (Araneae: Salticidae) // Zootaxa. Vol.3852. No.5. P.569-578.

Montesanto G. 2015. A fast GNU method to draw accurate scientific illustrations for taxonomy // Taiti S., Hornung E., Štrus J., Bouchon D. (eds.). Trends in Terrestrial Isopod Biology. ZooKeys. Vol.515. P.191-206. https://doi.org/10.3897/zookeys. 515.9459
Sanap R.V., Joglekar A., Prajapati D.A., Caleb J.T.D. 2017. Two new species of Langelurillus Próchniewicz, 1994 from India (Araneae: Salticidae: Aelurillina) // Zootaxa. Vol.4318. No.1. P.135-146. doi:10.11646/zootaxa.4318.1.6

Wanless F.R. 1981. A revision of the spider genus Hispo (Araneae: Salticidae) // Bulletin of the British Museum of Natural History (Zoology). Vol.41. P.179-198.

WSC 2018. World Spider Catalog. Natural History Museum Bern, online at http://wsc.nmbe.ch, version 19.5. [accessed 7 August 2018].

Responsible editor D.V. Logunov 


\section{6}
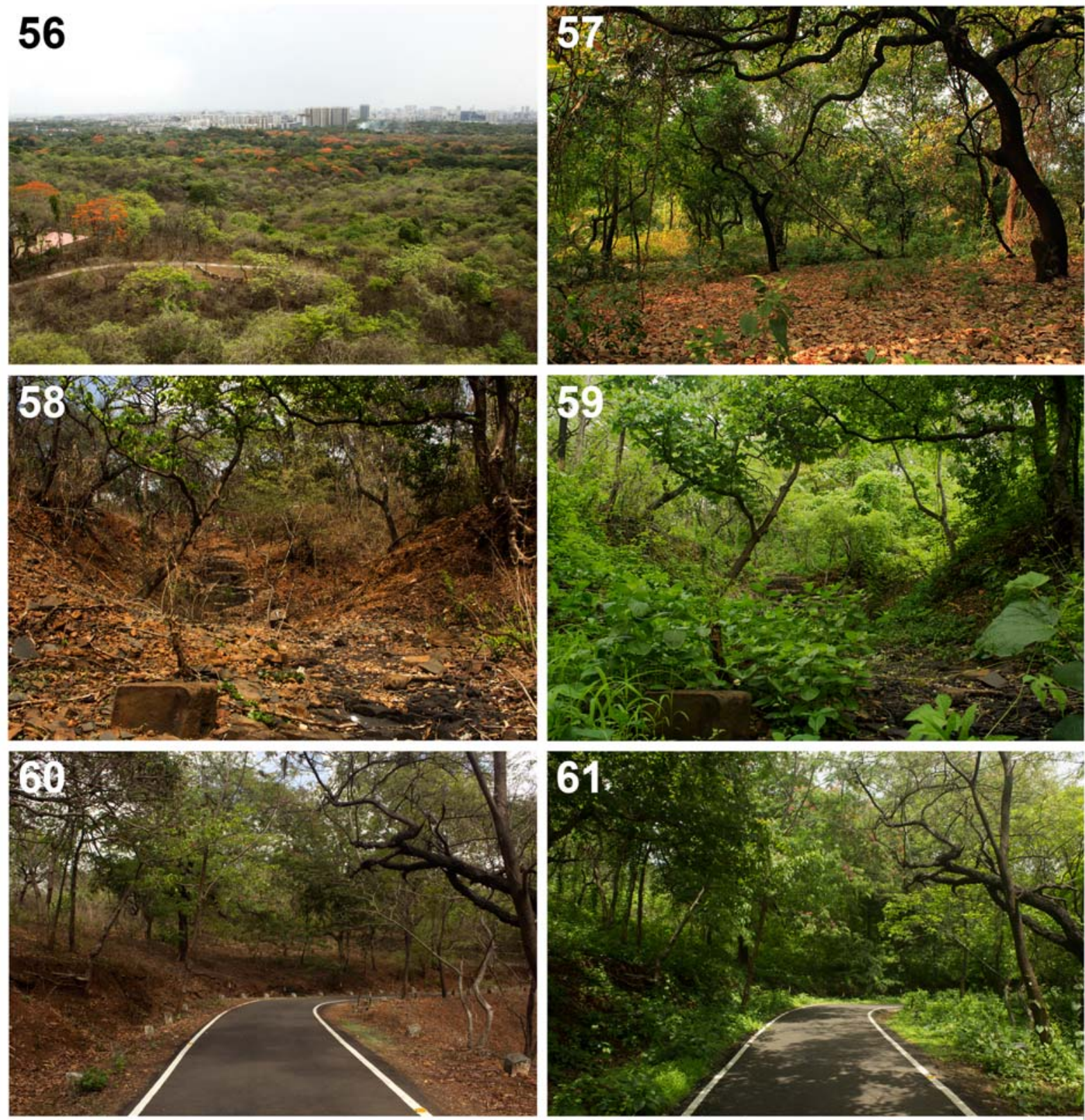

Figs 56-61. Habitat of Jerzego sunillimave sp.n. in Aarey Milk Colony, Mumbai, India: 56 — landscape; 57 — macrohabitat; 58-61 — seasonal variations in the vegetation cover (58,60 - during the summer; 59, 61 - during the monsoon).

Рис. 56-61. Местообитание Jerzego sunillimaye sp.n. в колонии Арей Милк, Мумбай, Индия: 56 — ландшафт; 57 — макроместообитание; 58-61 - сезонные изменения в растительном покрове (58, 60 - летом; 59, 61 — во время муссона). 